\title{
Advances in Agronomic Management for Ensuring Fodder Security in Semi Arid Zones of India- A Review
}

\author{
Hanamant M. Halli ${ }^{1 *}$, S.S. Rathore $^{2}$, N. Manjunatha ${ }^{1}$ and Vinod Kumar Wasnik ${ }^{1}$ \\ ${ }^{1}$ Indian Grassland and Fodder Research Institute, Jhansi-284003, India \\ ${ }^{2}$ Indian Agricultural Research Institute, New Delhi-110012, India \\ *Corresponding author
}

\section{A B S T R A C T}

\section{Keywords}

Livestock, Fodder security, Cultivable lands, Non-

cultivable lands, Year round fodder production, Water hycianth

\section{Article Info}

Accepted:

17 January 2018

Available Online:

10 February 2018
Livestock share to the total Indian agriculture gross value product is increasing gradually over the years. The growth rate of livestock sector is higher than the crop sector due to assured high income and increasing demand for milk and milk products. But the critical challenge is, per animal productivity with the existing feeding strategy and management practices. Main factor for lower livestock productivity in India is availability of quality feed and it alone contributes nearly $60 \%$ of the total milk production cost. The efficient utilisation of both cultivable and non-cultivable lands helps to improve the yield and system productivity for ensured fodder security. Inclusion of Maize + Cowpea-MP Chari + Cowpea - Berseem + Japanese rape system maintains the year round fodder production. Conservation of wilted water hycianth as silage for ruminants may be improved by the addition of molasses or rice bran. Water hyacinth can be successfully ensiled with either 4 $\%$ of sugarcane molasses or $15 \%$ of rice bran for ruminants. This helps in improving the resource use efficiency and reducing the feeding cost.

\section{Introduction}

Livestock is the important subsidiary enterprise in supplementation to the crop husbandry in India. The country has a vast and diverse livestock population. The share of Indian livestock sector to the gross value output of the country agriculture has been increasing continuously at faster rate than the crop sector. It was 14 per cent during 1980-81 and increased to 27 per cent in 2010-11. This sector creates large self-employment opportunities, nearly $70 \%$ of Indian population engaged in livestock production and management especially in rural areas. The milk production of the country has been considerably increased in the last 2 decades but the concern is about per animal productivity, which is much lower as compared to that in many developed and developing countries (Raju, 2013).

The total livestock population in the country has increased progressively with an increase of $15.8 \%$ in last two decades (1995-2015) as shown in Figure 1. The human population in 
India is expected to reach over 1400 million by 2025 with the shift in lifestyle and feeding habits towards milk products, meat products and eggs led to increase in demand of livestock. But the critical challenge with us is to improve the livestock productivity with the existing fodder resources and feeding strategy by technological intervention (Raju, 2013).

\section{Per animal productivity}

The productivity of livestock often remains low in Indian condition, which is 20 to $60 \%$ lower than the global average. This is the major concern, if we trace out the possible reasons, deficiency of feed and fodder accounts for half of the total loss followed by the problems of health, breeding and reproduction and management. Ever increasing livestock population has widen the gap between forage demand and supply in the country. Around $80 \%$ of the livestock are with marginal, small and medium holdings under rain fed situation. Whereas, small ruminants are mostly reared under nomadic (30\%) and sedentary (70 \%) systems.

Among these, fodder feed being the main factor in livestock production and needs to be addressed, because the feed alone constitutes 60 to $70 \%$ of the milk production cost. Thus, any attempt towards enhancing livestock productivity should consider the feed availability. A balanced diet will keep an animal healthy and productive, it doesn't mean only purchased mineral mixtures. Instead of buying expensive concentrates, there are a variety of leguminous plants rich in protein which can be grown in the farm (Raju, 2013).

\section{Forage and feed resources in India}

Among different resources, crop residues are major one and generally defined as feedstuffs, which are bulky and contain higher fibre content (18\%). These are the major feed resource for livestock across all states. At the national level, out of the total $574.3 \mathrm{~m}$ t of dry matter available, $62.5 \%$ is accounted by crop residues. The increase in the availability of crop residues over the years has largely been due to increase in production of paddy, wheat and other crops resulting in higher grain production and consequently higher availability of straws from these crops. Concentrates are less bulky they contain less than $18 \%$ fibre and rich in energy-yielding nutrients. Concentrates comprise of cereal and pulse grains and their byproducts, oilseeds and their products and animal products.

\section{Green fodder}

There has not been much improvement in the availability of dry matter through green fodder over the years, which is a matter of concern. The area under fodder cultivation has almost remained stagnant at around $4 \%$ of the total cropped area in the country. Excluding in the sugarcane growing belts, where sugarcane tops availability has increased by almost $29 \%$. It needs to be managed proficiently in livestock diet to make production system more profitable. Contrary to the belief that there has been a decline in the availability of feed resources, but the data clearly shows that the overall dry matter availability from different sources has increased over the years. The increased availability of feed resources was chiefly due to the increase in the crop residues and to a limited extent by increase in the concentrates. Availability of greens was more or less decreasing over the years (Anonymous, 2013).

\section{Present scenario of forage and feed supply}

At present, the country faces a net deficit of $63.5 \%$ green fodder, $23.5 \%$ dry crop residues and $64 \%$ feeds (2015). Supply and 
demand scenario of forage and roughage and grazing resources are presented in Table 1. In animal feed supply, coarse cereals have a major role and four major cereals viz., maize, barley, sorghum and pearl millet account for about $44 \%$ of the total cereals (Anonymous, 2011).

Agro-technologies to improve fodder production and post harvest management for year-round forage production

Many technological interventions we can made in multidisciplinary approach to improve the livestock productivity through increased fodder availability and accessibility (Anonymous, 2011a).

Cultivation from arable land

Cultivation from non-arable land

Management of grassland or trees

Storage of fodder and value addition

\section{Cultivation of forages from arable lands}

There is need for strengthening of location specific technologies for forage production, forage cropping systems and other land use strategies to achieve higher production. Also there is need to work out the production cost of system. Identification of suitable varieties or cropping system to match with changing climate scenario (like high $\mathrm{CO}_{2}$, temperature) and drought or secondary salinization. The study conducted by many authors elsewhere regarding management of arable forages are discussed here. Identification of suitable genotypes is most important to harness the natural resources with higher yield in forage crops. Seed pelleting with combination of nutrient mixture, cold solution of $\mathrm{KNO}_{3}(0.2$ $\%$ ) and Bavistin as fungicide recorded enhanced the germination, also boosted the growth and reduced mortality of grass seedling (Maity et al., 2017). Agronomic enriching of crop plants nutrient status improves the nutritional value of the feed. In maize and wheat, treatment applied with 60 $\mathrm{kg} \mathrm{K}$ through muriate of potash $+30 \mathrm{~kg} \mathrm{~K}$ through farmyard manure resulted in enriched crop residues with higher concentration of macro and micro nutrients (Kumar et al., 2014). Suitable planting methods with perennial grass and legume combination i.e., Cenchrus ciliaris + Desmanthus virgatus in 1: 1 proportion on ridges and furrows had recorded higher net monetary returns of Rs. 55529 ha/year, maize fodder equivalent yield of $308 \mathrm{qha}^{-1}$ and benefit cost ratio of 2.72 (Kauthale et al., 2017). Field demonstration activities are also important in order to promote the improved technologies and fodder varieties. Field demonstration of fodder sorghum variety MP Chari in an area of 4.0 ha covering 18 farmers in different districts of Uttarpradesh and Uttarakhand showed minimum yield advantage of $16 \%$. All the improved varieties in different fodder crops have potential to enhance the fodder yield during kharif season (Atar et al., 2017). The varieties in major cultivated forage crops (Table 2) with the important agronomic practices are given and discussed here (Table $3)$.

\section{Year-round forage production through combination of perennial and annual forages}

The sequence and overlapping cropping systems were developed and evaluated at the IGFRI, Jhansi, to meet the green fodder need of dairy around the year for small farmers from a piece of land. It includes raising of berseem, inter-planted with hybrid Napier in spring and intercropping the inter-row spaces of the grass with cowpea during summer after the final harvest of berseem (Table 4). This system found superior to multiple crop sequences in terms of both production and economics. The hybrid Napier could be successfully replaced with relatively soft and 
palatable perennial grasses like Setaria and Guinea grass and berseem with lucerne wherever required.

\section{Enhancing the forage production from non-arable land}

We can also improve the forage production from non-arable ecosystem mainly by bringing the area in to alternate land use systems such as hortipasture, silvipasture and agro-hortisilvipasture in different agro climatic zones based on suitability, in situ soil and moisture conservation and tree grass combination. It also helps in improving the resource use efficiency and livelihood. Here we discussed some of the research reports regarding improvement of forage production from non arable lands. The combination of tree and grass species improved the system productivity and sustainability. The best tree pasture combination for higher forage yield (>10 t/ha) is Morus alba/Ficus infectoria with Panicum maximum and Sesbania seabrana under rainfed conditions in non-arable lands in semi-arid region of India. The leaf fodder percentage in pruned biomass which indicates quality of forage is maximum $(22.5 \%)$ in Madhuca latifolia and minimum in Acacia nilotica (Kumar et al., 2017). In situ soil and moisture conservation practices also enhance the rain water harvesting and system productivity. Construction of bunds recorded significantly maximum moisture content (7.79-9.28\% at $15 \mathrm{~cm}$ soil depth and 8.03$11.73 \%$ at $30 \mathrm{~cm}$ soil depth during OctoberApril) followed by staggered trenches. This also resulted in significantly higher total crude protein yields from pasture (457.0$711.4 \mathrm{~kg} \mathrm{ha}^{-1}$ ) than control treatment (Ram et al., 2017). Agroforestry system also acts as an important solution in addressing the environmental issues in supplementation with improved forage production. More and more adoption of agroforestry on dry and degraded lands in a participatory mode will improve dry land productivity and economic status of farmers. This also focusses on issues related to mitigating climate change, soil fertility enhancements, improving efficiency of use of soil, water and fertilizers (Roy, 2016). The productivity of such lands can be increased through integration technologies by selecting hardy and suitable crop varieties. The list of some released forage varieties for problematic (degraded) ecosystem are given (Table 5).

\section{Grassland restoration and trees management}

Restoration and management of grassland or forest ecosystem helps in improving the fodder availability and addressees the issues like land degradation by soil and water erosion. Some of the restoration techniques like reseeding, legume seeding and other soil moisture conservation techniques. Some of the reported studies are discussed here. Silvipasture system acts as sustainable system to maintain the livestock fodder demand and components yield through the year. The higher herbage yield of $3.16 \mathrm{t} / \mathrm{ha}$, dry matter, protein yield, grass seed yield and ber fruit yield were recorded higher under ber + Cenchrus setigerus plantation as compared to ber + Cenchrus ciliaris silvipasture system (Meena et al., 2017). The top feed trees plays a crucial role, especially in small ruminants during lean period to maintain the livestock productivity. But the un tapped issue is, their suitability to livestock interms of nutritional value and acceptability. For example, the legume and non-legume tree leaves were assessed for their nutritional value, mean crude protein contents of top feeds were higher for legume $(21.91 \%)$ than non-legume $(16.07 \%)$ tree species, while fiber contents were comparable between legume and nonlegume tree species. The condensed tannin levels were less than the threshold value $(\sim$ $5 \%$ ) baring three non-leguminous plants. The macro and micro mineral contents varied 
from plant to plants. Thus most of evaluated top feeds are rich in protein, low in tannin, adequate to deficit in macro and micro minerals and may be utilized as protein and mineral feed resources with suitable supplementation as per the requirement (Nag Subir et al., 2017). The study conducted by Sahoo et al. (2016) to evaluate leaves of 11 tree species commonly used for livestock foraging in low (1000-1500 metres) and high (2000-2500 metres) altitudes of temperate sub Himalayas in Northern India for their nutritional values. Leaves had wide variation in crude protein, fibre, total tannin, condensed tannin (0.02-5.82 \%) and hydrolysable tannin $(0.50-9.20 \%)$. In most of the tree leaves $\mathrm{Cu}$ $(5.2-8.0 \mathrm{ppm})$ and I (0.05-0.09) contents were below critical level. The concentration of minerals in foliages grown in high elevation was found to be lower than low elevation. Most of the tree leaves are good source of protein and fibre. The study conducted by Richard et al. (2017) to examine the productivity and persistence of mixed pastures. Also compared the productivity and persistence of subterranean clover with alternative annual legume species biserrula (Biserrula pelecinus L.) and strand medic (Medicago littoralis Rhode ex Loisel). Subterranean clover regeneration in year 3 was $29 \%$ higher and total cumulative biomass $13 \%$ higher where subterranean clover was sown in a 1:1 configuration with lucerne than where the species were mixed together in every drill row (Table 5).

Table.1 Supply and demand scenario of forage and roughage till 2020

\begin{tabular}{|c|c|c|c|c|}
\hline \multirow{2}{*}{ Year } & \multicolumn{2}{|c|}{ Supply } & \multicolumn{2}{c|}{ Deficit as \% of demand } \\
\cline { 2 - 5 } & Green & Dry & Green & Dry \\
\hline $\mathbf{1 9 9 5}$ & 379.3 & 421 & 59.95 & 19.95 \\
\hline $\mathbf{2 0 0 0}$ & 384.5 & 428 & 61.1 & 21.93 \\
\hline $\mathbf{2 0 0 5}$ & 389.9 & 443 & 61.96 & 22.08 \\
\hline $\mathbf{2 0 1 0}$ & 395.2 & 451 & 62.76 & 23.46 \\
\hline $\mathbf{2 0 1 5}$ & 400.6 & 466 & 63.5 & 23.56 \\
\hline $\mathbf{2 0 2 0}$ & 405.9 & 473 & 64.21 & 24.81 \\
\hline
\end{tabular}

Source: Based on $10 \& 11^{\text {th }}$ five year plan document

Table.2 Major cultivated forage crops and varieties

\begin{tabular}{|l|l|}
\hline Crop & Varieties released \\
\hline Sorghum & PC-6 \&9, MP Chari, UP Chari \\
\hline Maize & African Tall, J-1006 \\
\hline Pearl millet & Giant bajra, Raj. Bajra chari-2, AVKB-19 \\
\hline Cowpea & Bundel lobia-1 \&2, UPC-5287, UPC-620 \\
\hline Guar & Bundel guar- $1,2 \& 3$ \\
\hline NB hybrid & IGFRI- 6 \&10, CO- 1,2, 3 \\
\hline Guinea grass & Bundel guinea- 1 \&2, PGG-9 \&16 \\
\hline Dinanath grass & Bundel Dinanath -1 \&2 \\
\hline Oats & JHO-851, JHO-822, Kent, UPO-212 \\
\hline Berseem & Wardan, JB-2, JB-3, BL-2 \\
\hline
\end{tabular}


Table.3 Forage production from arable lands

\begin{tabular}{|l|l|l|}
\hline Authors & Practices & Findings \\
\hline $\begin{array}{l}\text { Mut } \text { et al., } \\
\mathbf{2 0 1 7}\end{array}$ & Inter cropping & $\begin{array}{l}\text { Intercropping of maize with soybean at the seed rate of 50:100 was the } \\
\text { most suitable choice with respect to hay and protein yields. }\end{array}$ \\
\hline $\begin{array}{l}\text { Dixit } \text { et al., } \\
\mathbf{2 0 1 7}\end{array}$ & $\begin{array}{l}\text { Nutrient } \\
\text { management in } \\
\text { cropping system }\end{array}$ & $\begin{array}{l}\text { Application of FYM, P and S increased the equivalent yield and nutrient } \\
\text { uptake of sorghum + cowpea - chickpea cropping system significantly. }\end{array}$ \\
\hline $\begin{array}{l}\text { Kauthale } \boldsymbol{e t} \\
\text { al., 2017 }\end{array}$ & $\begin{array}{l}\text { Grass and legume } \\
\text { mixtures with } \\
\text { planting methods }\end{array}$ & $\begin{array}{l}\text { Green fodder, dry matter and crude protein yields were significantly } \\
\text { increased with planting of perennial grass and legume combination, } \\
\text { Cenchrus ciliaris + Desmanthus virgatus in 1:1 proportion on ridges and } \\
\text { furrows. }\end{array}$ \\
\hline $\begin{array}{l}\text { Lindsay } \text { et al., } \\
\mathbf{2 0 1 7}\end{array}$ & $\begin{array}{l}\text { Lay cropping with } \\
\text { legumes }\end{array}$ & $\begin{array}{l}\text { New forage legume options like lablab and burgundy bean showed } \\
\text { potential to increase N supply in lay cropping system and contributing } \\
\text { significant fixed N (75 to 150 kg/ha) and increasing available soil N for } \\
\text { subsequent crops as compared to non-legume forage crops. }\end{array}$ \\
\hline $\begin{array}{l}\text { Choudhary } \text { et } \\
\text { al., 2017 }\end{array}$ & $\begin{array}{l}\text { Irrigation } \\
\text { management }\end{array}$ & $\begin{array}{l}\text { The significant response of growth, dry fodder yield and nutrient uptake of } \\
\text { oat was observed up to irrigation at 1.0 IW/CPE. It increased the green and } \\
\text { dry fodder yields by 11.8 and 7.3\%, respectively over 0.8 IW/CPE. }\end{array}$ \\
\hline $\begin{array}{l}\text { Palsaniya } \text { et } \\
\text { al., 2015 }\end{array}$ & Weed management & $\begin{array}{l}\text { The genotype, JHO-99-2 can be recommended as a fodder variety in } \\
\text { Bundelkhand region. This variety was found a strong competitor to weed } \\
\text { and produced highest green fodder yield. }\end{array}$ \\
\hline
\end{tabular}

Table.4 Round-the-year fodder production systems

\begin{tabular}{|l|c|}
\hline \multicolumn{1}{|c|}{ Crop sequence } & $\begin{array}{c}\text { Green fodder yield } \\
\text { (t/ha/year) }\end{array}$ \\
\hline Napier x Bajra hybrid + Cowpea - Berseem & 260 \\
\hline $\begin{array}{l}\text { Maize + Cowpea - MP Chari + Cowpea - Berseem + Japanese } \\
\text { rape }\end{array}$ & 197 \\
\hline MP Chari + Cowpea - Berseem + Japanese rape & 184 \\
\hline Cowpea - MP Chari + Cowpea - Berseem + Japanese rape & 176 \\
\hline Napier x Bajra hybrid + Cowpea - Berseem - Cowpea & 255 \\
\hline
\end{tabular}

(Source: Anonymous, 2011)

Table.5 Grassland restoration and trees management

\begin{tabular}{|l|l|}
\hline Author & Findings \\
\hline Meena et al., 2017 & $\begin{array}{l}\text { Integrated application of 50\% RDF (NPK) through fertilizers and } \\
50 \% \text { through sheep manure brought significant improvement in } \\
\text { growth and yield attributes of grasses followed by 100\% RDF } \\
\text { through fertilizers. }\end{array}$ \\
\hline $\begin{array}{l}\text { Animal production per hectare was greatest for fast rotations (56 } \\
\text { days rest) at high stocking rates but continuous grazing was } \\
\text { equally productive. Intensive rotational grazing could be } \\
\text { effectively managed by using green herbage allowance. }\end{array}$ \\
\hline
\end{tabular}


Fig.1 Livestock population of the country over years (million adult cattle unit)

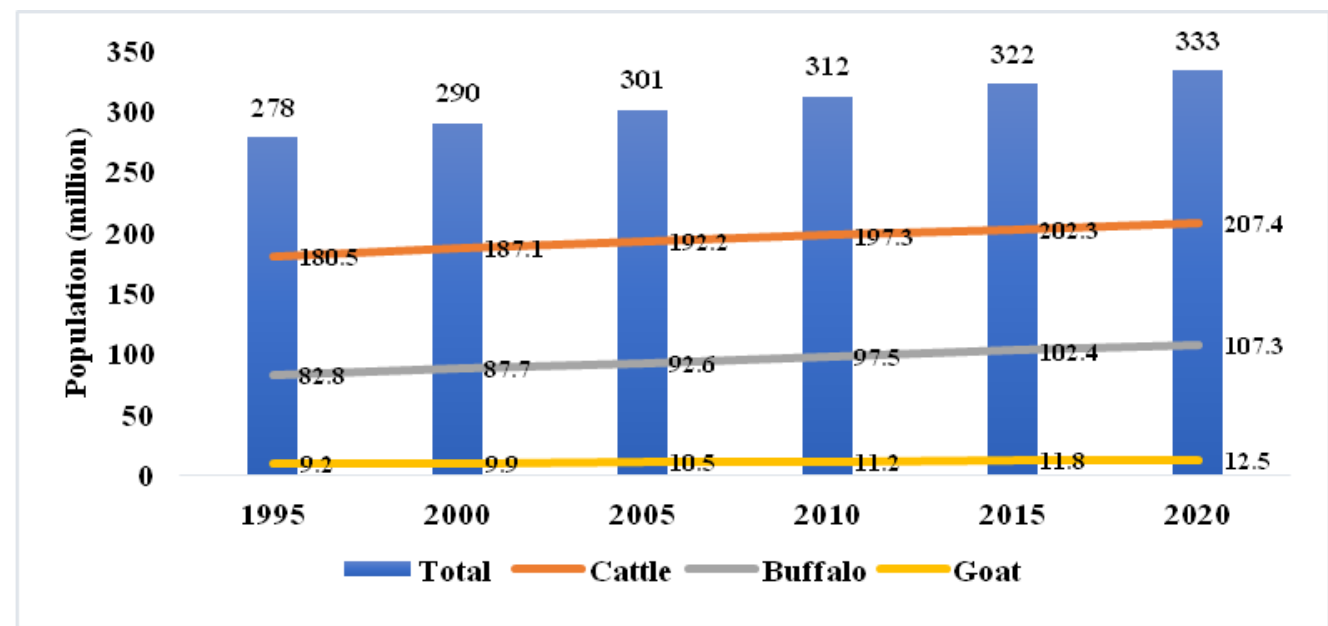

(Source: Based on $10 \& 11^{\text {th }}$ five year plan document)

\section{Good agronomic practices for efficient fodder production}

These practices vary with region to region, some of the important points need to be considered are,

- Preparation of proper seed bed and timely sowing

- Sowing/planting of fodder seeds/material with assured germination and vigour

- Use of suitable planting methods and geometry and adjust based on the purpose

- It is better to go for multi-cut fodder crops for efficient utilization of resources

- Go for diversified cropping like grasses and legumes to improve nutritional security

- It is advisable to take care of weeds before emerging through cultural method and pre-emergence herbicides

- Integrated nutrient management should be followed based on soil test report, give emphasis on crop rotation and green manuring

- Irrigation scheduling based on soil type, climate and crop growth stage. For crops like maize, cowpea and bajra drainage is also important
- Go for non-chemical methods of pest and disease control, harvest the crop after 2025 days of chemical spray

- Harvest the grasses at 50 per cent flowering and legumes at initiation of pod filling stage generally to ensure fodder palatability and acceptability

- Adopt alternate land use systems like agrisilvipasture and tree based fodder production system

Post-harvest management and value addition of forage

Post-harvest management of forage or fodder is very much essential in order to reduce the losses during surplus production, ensure the fodder availability during lean period, to improve the self-life of feed and the quality of roughages. There are many methods involved are, hay making, silage making, pallets making, bundles making, value addition and any other locally available methods.

\section{Hay making}

Is the process of turning green, perishable forage into a product that can be safely stored and easily transported without changing much in the nutritional value, quality or aroma. This 
mainly involves curing process, where reducing its moisture content by drying the forage in the sun. Hay feeding to livestock reduces the amount of concentrates and the cost of feeding. It can be fed to livestock safely without any problems, the sheep and goats can be fed excess hay.

\section{Silage making}

Silage is prepared by controlled fermentation, under anaerobic conditions with high moisture content in the forages. Silage is produced by naturally-occurring bacteria that convert plant sugars into organic acids that preserve nutritional qualities. For silage the material should contain moisture content in between 60 to $70 \%$ and $\mathrm{pH}$ below 4.2 to 4.8 .

\section{Water hyacinth weed silage}

We can also utilize naturally occurring fresh hyacinth for silage making. Take weed from a clean water body without roots, chop the shoots of the plant into pieces and air dry. Mix thoroughly the plant pieces with maize bran in the ratio of 11:1 respectively; making sure the bran coats the pieces evenly. If the water hyacinth is too dry sprinkle some water over the water hyacinth and re-mix the materials together. Tightly pack the mixture into a large, air-tight plastic bag and close bag with string or wire. Stack 3 to 4 bags in an upside-down position. Place the bags away from the sun or cover with a non-transparent sheet. The contents will turn from green to olive to brown during the first week. The silage is ready for use after 14 to 20 days and can be stored for several months without loss of quality. Silage may be prepared by substituting molasses for maize brain but the resulting feed is lower in dry matter and crude protein. The silage resulting without addition of either maize bran or molasses has poor nutritional value and storage characteristics. The study conducted by Das et al. (2017) and reported that, the cost of urea treatment of straw in mechanized process was only Rs. 26 per quintal. Conservation of surplus forage as hay or silage provides the opportunity to ensure livestock have access to high quality forage around the year (Marsetyo et al., 2013). Untreated rice straw can be used as a maintenance diet for Ongole cows with low energy requirements when supplemented with tree legumes at $12 \mathrm{~g} \mathrm{DM} / \mathrm{kg}$ or $2.8 \mathrm{~g} \mathrm{DM} / \mathrm{kg}$ (Syahniar et al., 2012). The technologies will help in the value addition and utilization of various tanniniferous feed, fodder and agroindustrial byproducts and solve the problem of shortage of conventional feed and fodder in the developing countries (Bhat et al., 2013). The results obtained in lab-scale silos suggest that the ensiling of water hycianth on a larger scale could be a viable alternative to farmers and could serve as a source of roughage for ruminants in the tropics (Thanh et al., 2013, Sophal, 2010 and Abdalla et al., 1987).

Based on the above discussion we may conclude that, fodder availability can be improved through agronomic practices by improving the productivity of both cultivated and non cultivated lands. Grassland restoration and trees management in supplementation with post harvest care provides the year round fodder security to sustain the livestock production in semi arid region of the country.

\section{References}

Abdalla, A. L., E. J. Ambrosano, E.J.,D. M. S. S. Vitti, D.M. and F. J. C. Silva, F.J.C., 1987. Water-hyacinth (Eichhornia crassipes) in ruminant nutrition. Water Sci.ence \&and Tech.nology 19:109-112.

Anonymous, 2011. Handbook of Agriculture, 2011, Indian Council of Agricultural Research, New Delhi Publication, pp: 13531417.

Anonymous, 2011a. Vision document-, 2030, Indian Grassland and Fodder Research Institute

Jhansi, Uttar Pradesh, Printed on July 2011. 
Anonymous, 2013. Indian Harvest Compact Disc, 2004. Centre for Monitoring Indian Economy.

Atar, S., Gautam, U.S., Singh, A.K., Ghosh, P.K., Dubey, S.K., Srivastava, A.K., Singh, A.K., 2017. Effect of fodder demonstrations in rainfed conditions of Uttar Pradesh and Uttarakhand states of India. Range Mgmt. \&Management and Agroforestry. 38(1): 147-150.

Badgery, W., Millar, G., Broadfoot, K., Martin, J., Pottie, D., Simmons, A. and Cranney, P., 2017. Better management of intensive rotational grazing systems maintains pastures and improves animal performance. Crop and Pasture Sci. 68(12): 1131-1140

Bhat, T.K., Kannan, A., Birbal Singh, Sharma, O.P., 2013. Value Addition of Feed and Fodder by Alleviating the Antinutritional Effects of Tannins. Agric. Res. 2(3): 189206.

Choudhary, M. and Prabhu, G., 2017. Response of fodder oat (Avena sativa L.) varieties to irrigation and fertilizer gradient. Range Mgmt. \& and Agroforestry Range Management and Agroforestry. 37(2): 201206.

Das, M.M., Singh, K.K., Misra, A.K., Pathak, P.K., Kumar Anil, Pandey Sadhana and Das, N. 2017. Development of on-farm mechanized urea treatment process during threshing and utilization of urea treated wheat straw in lactating Murrah buffaloes (Bubalus bubalis). Range Mgmt. \& and Agroforestry. 38(1): 115-120.

Dixit, A.K., Sunil Kumar, Rai, A.K., Palsaniya, D.R. and Mukesh Choudhary, 2017. Nutrient management in fodder sorghum + cowpea - chickpea cropping system for higher system productivity and nutrient use. Range Mgmt. Agroforestry. 38(1): 82-88.

Eleventh Five Year Plan (2007-2012). Agriculture, Rural Development, Industry, Services and Physical Infrastructure. Volume III Planning Commission Government of India (http://planning commission.nic.in/plans/planrel/fiveyr/11th /11_v3/11th_vol3.pdf).

Kauthale, V.K., Takawale, P.S., Patil, S.D., 2017. Fodder productivity influenced by various grass-legume combinations and planting methods in western Maharashtra. Range Mgmt. \& and Agroforestry. 38(1): 96-99.

Kumar, R.V., Singh, H.V., Sunil Kumar, Roy, A.K. and Singh, K.A., 2017. Growth and biomass production of fodder trees and grasses in a silvipasture system on nonarable land of semi-arid India. Range Mgmt. \& and Agroforestry. 38(1): 43-47.

Kumar, S., Dhar Shiva, Kumar Dileep, Kumar Bipin, Meena Ranglal and Hariom, 2014. Bio fortification of crop residues for animal feeding in maize-wheat cropping system through integrated potassium management. Range Mgmt. \& and Agroforestry. 35(2): 220-226.

Lindsay, W., Bell, John Lawrence, Brian Johnson and Mark, B.P., 2017. New ley legumes increase nitrogen fixation and availability and grain crop yields in subtropical cropping systems. Crop and Pasture Sci. 68(1): 11-26.

Maity, A., Vijay, D., Singh, S.K. and Gupta, C.K., 2017. Layered pelleting of seed with nutrient enriched soil enhances seed germination in Dinanath grass (Pennisetum pedicellatum). Range Mgmt. Agroforestry. 38(1): 70-75.

Marsetyo, A., Muhammad Shoaib Tufail, B., Samuel Mbuku, C., Mupenzi Mutimura, D., Xusheng Guo, E. and John Piltz, F., 2013. Utilisation of conserved forage to improve livestock production on smallholder farms in Asia and Africa. 22 $2^{\text {nd }}$ International Grassland Congress "Revitalising grasslands to sustain our communities", At Sydney, New South Wales, Australia, Improving livelihoods from grasslands by balancing human needs and the environment. 3: 1731-35.

Meena, L.R., Yadav, R.S. and Kumar Sanjeev, 2017. Enhancing productivity, profitability and soil health through integrated nutrient management in ber-based hortipasture system in Rajasthan. Range Mgmt. \& and Agroforestry. 38(1): 100-107.

Mut, H., Erdem Gulumser, Medine Copur Dogrusoz and Ugur Basaran, 2017. Forage yield and nutritive value of maize-legume mixtures. Range Mgmt. Agroforestry. 38(1): 76-81.

Nag Subir, K., Singh Sultan, Raman, R.K., 
Mahanta, S.K., Bhadoria, B.K., 2017. Nutritional value of top feeds from Dharwad region of Karnataka with special reference to mineral contents. Range Mgmt. Agroforestry. 38(1): 108-114.

Palsaniya, D.R., Kumar, T., Prabhu, G., Dixit, A.K., Rai, A.K., Kumar Sunil, 2015. Weed dynamics in fodder oat (Avena sativa $\mathrm{L}$.) genotypes. Range Mgmt. Agroforestry. 37(1): 107-108.

Raju, S.S., 2013. Assessment of Feed Resources and its impact on livestock output in India. Agril. Situation in India. 69(12): 5-11.

Ram, S.N., Roy, A.K., Shukla, A.K., 2017. Effect of moisture conservation practices on performance of Anjan (Hardwickia binata) tree based silvipasture systems. Range Mgmt. Agroforestry. 37(2): 222-227.

Richard, C., Hayes, Guangdi, D. Li, Graeme, A., Sandral, Tony, D., Swan, Andrew Price, Shane Hildebrand, Laura Goward, Chris Fuller and Mark, B. P., 2017. Enhancing composition and persistence of mixed pasture swards in southern New South Wales through alternative spatial configurations and improved legume performance. Crop and Pasture Sci. 68(12): $1112-1130$.

Roy, M.M., 2016. Agroforestry on dry and degraded lands: present status and future prospects. Range Mgmt. \& and Agroforestry. 37(1): 1-11.

Sahoo, B., Garg, A.K., Mohanta, R.K., Bhar, R., Thirumurgan, P., Sharma, A.K., Pandey, A.B., 2016. Nutritional value and tannin profile of forest foliages in temperate subHimalayas. Range Mgmt. \& and Agroforestry. 37(2): 228-232.

Sophal, C., 2010. Effects of supplements of water hyacinth and cassava hay on the performance of local "yellow" cattle fed a basal diet of rice straw. Master thesis, Swedish University of Agricultural Sciences, Uppsala, Sweden.

Syahniar, T.M., Antari, R., Pamungkas, D., Marsetyo , Mayberry, D.E., Poppi, D.P., 2012. The level of tree legumes required to meet the maintenance energy requirements of Ongole (Bos indicus) cows fed rice straw in Indonesia. Animal Prod. Sci. 52: 641646.

Thanhm H.T., Ngo V.M and Thomas, P., 2013. Fermentation Quality of Ensiled Water Hyacinth (Eichhornia crassipes) as affected by additives. Asian-Austrelian Journal of Animal Sci.ences. 26(2): 195-201.

\section{How to cite this article:}

Hanamant M. Halli, S.S. Rathore, N. Manjunatha and Vinod Kumar Wasnik. 2018. Advances in Agronomic Management for Ensuring Fodder Security in Semi Arid Zones of India- A Review. Int.J.Curr.Microbiol.App.Sci. 7(02): 1912-1921. doi: https://doi.org/10.20546/ijcmas.2018.702.230 